Article

\title{
Are You Happy to Be a Farmer? Understanding Indicators Related to Agricultural Production and Influencing Factors: GAP-Şanliurfa, Turkey
}

\author{
Mustafa Hakkı Aydoğdu ${ }^{1}$, Mehmet Cançelik ${ }^{2}$, Mehmet Reşit Sevinç ${ }^{3, *} \mathbb{D}$, Mehmet Ali Çullu ${ }^{4}$, Kasım Yenigün ${ }^{5}$, \\ Nihat Küçük ${ }^{6}$, Bahri Karlı ${ }^{7}$, Şevket Ökten ${ }^{8}$, Uğur Beyazgül ${ }^{9}$, Hatice Parlakçı Doğan ${ }^{10}{ }^{10}$, Gönül Sevinç ${ }^{1}($, \\ Zeliha Şahin ${ }^{1}$, Nusret Mutlu ${ }^{11}$, Celal Kaya ${ }^{11}$, Ayla Yenikale ${ }^{11}$ and Akif Yenikale ${ }^{11}$
}

check for updates

Citation: Aydoğdu, M.H.; Cançelik, M.; Sevinç, M.R.; Çullu, M.A.; Yenigün, K.; Küçük, N.; Karlı, B.; Ökten, S..; Beyazgül, U.; Doğan, H.P.; et al. Are You Happy to Be a Farmer? Understanding Indicators Related to Agricultural Production and Influencing Factors: GAP-Şanlıurfa, Turkey. Sustainability 2021, 13, 12663. https://doi.org/10.3390/su132212663

Academic Editors: Bazyli Czyżewski, Sebastian Stępień and

Łukasz Kryszak

Received: 3 November 2021

Accepted: 14 November 2021

Published: 16 November 2021

Publisher's Note: MDPI stays neutral with regard to jurisdictional claims in published maps and institutional affiliations.

Copyright: (c) 2021 by the authors. Licensee MDPI, Basel, Switzerland. This article is an open access article distributed under the terms and conditions of the Creative Commons Attribution (CC BY) license (https:// creativecommons.org/licenses/by/ $4.0 /)$.
1 Department of Agricultural Economics, Faculty of Agriculture, Harran University, Şanlıurfa 63050, Turkey; mhaydogdu@harran.edu.tr (M.H.A.); gsevinc@harran.edu.tr (G.S.); zelihasahiin@gmail.com (Z.Ş.)

2 Department of Social Science Vocational School, Harran University, Şanlıurfa 63200, Turkey; m.cancelik@harran.edu.tr

3 Department of Bozova Vocational School, Harran University, Şanlıurfa 63850, Turkey

4 Department of Soil Science and Plant Nutrition, Faculty of Agriculture, Harran University, Şanlıurfa 63050, Turkey; macullu@harran.edu.tr

5 Department of Civil Engineering, Faculty of Engineering and Architecture, Kastamonu University, Kastamonu 37150, Turkey; kyenigun@kastamonu.edu.tr

6 Department of Economics, Faculty of Economics and Administrative Sciences, Harran University, Şanlıurfa 63050, Turkey; nihatk@harran.edu.tr

7 Department of Agricultural Economics, Faculty of Agriculture, Isparta University of Applied Sciences, Isparta 32200, Turkey; bahrikarli@isparta.edu.tr

8 Department of Sociology, Faculty of Arts and Sciences, Harran University, Şanlıurfa 63050, Turkey; sevketokten@gmail.com

9 Şanlıurfa Technology Development Zone, Harran University, Şanlıurfa 63050, Turkey; ugurbeyazgul@hotmail.com

10 Agricultural Education Center and GAP Agricultural Research Institute, Republic of Turkey Ministry of Agriculture and Forestry, Sanlıurfa 63330, Turkey; hparlakcidogan@yahoo.com

11 Southeastern Anatolia Project (GAP) Regional Development Administration, Republic of Turkey Ministry of Industry and Technology, Sanlıurfa 63330, Turkey; nmutlu@gap.gov.tr (N.M.); celalkaya@gap.gov.tr (C.K.); ayyenikale@gap.gov.tr (A.Y.); akyenikale@gap.gov.tr (A.Y.)

* Correspondence: rsevinc@harran.edu.tr; Tel.: +90-414-318-3749

\begin{abstract}
Recently, agricultural production areas and farmer numbers have been decreasing in Turkey, which has started to cause concern. This study aimed to analyze the satisfaction levels of farmers in different irrigation areas in the Southeastern Anatolia Project (GAP)-Şanlıurfa region, based on indicators related to agricultural production and influencing factors. The data were obtained through face-to-face surveys with farmers in 2020 and analyzed by logistic regression in STATA. According to the results, $43.3 \%$ of the farmers are happy to be farmers in the current situation, and $35.6 \%$ want their children to continue farming activities. It was determined that the area of irrigation, education level, income, and farming experience were statistically significant at different rates in terms of the happiness of the farmers. On the other hand, livestock, number of households, and land size were not statistically significant. While $27.5 \%$ of the participants were fully satisfied with the given public support, $15.7 \%$ were satisfied with the market selling prices of their products, and $43.5 \%$ stated that effective organizations are needed to live well. To ensure agricultural sustainability in the research area, there is a need for more agricultural support, effective extension services, and the development of rural tourism with the participation of the public and private sectors. This study was the first of its kind to be conducted in Turkey.
\end{abstract}

Keywords: farmer happiness; sustainable agricultural production; rural development; agricultural supports and extension; GAP-Şanlıurfa-Turkey 


\section{Introduction}

All living things require energy to maintain their vital activities, which they obtain through nutrients. Regardless of the level of development globally, agricultural production is of vital importance for all countries [1-7]. Today, rapid population growth, ever-increasing and diversifying consumption habits, the availability of natural resources, environmental problems, global warming, and climate change are causing global concerns regarding the amount, quality, diversity, and adequacy of agricultural production and food security [8-20]. Furthermore, agricultural production also has strategic importance due to its direct and indirect effects on the socioeconomic structures of countries [21-23].

All over the world, agriculture is supported in various ways due to its unique structure and importance. Among the most important reasons for supporting agricultural production compared to other sectors are that it has higher risks and uncertainties, lower investment attractiveness, a slow rate of investment capital, limited storage and marketing opportunities in rural areas, and is performed in more natural environments and conditions than other industries $[5,24,25]$. Support policies may differ according to the social, political, and economic structures of each country. These policies generally serve the purposes of directing the production of agricultural products, supporting the producer, raising the welfare level in rural areas, preventing migration to cities, fighting poverty, increasing the level of national welfare, and ensuring food security, as well as maintaining social, economic, and political balance [5,6,24-28]. It can be seen that poverty is more common in rural areas than in cities in many countries around the world [26]. Whichever criterion is chosen in the evaluation, poverty is higher in rural areas and declines more slowly there than in cities $[29,30]$.

According to the results of the Address-Based Population Registration System, the average household size in Turkey, which was 4 people in 2008, has been decreasing over time, down to 3.30 people in 2020. The province with the highest average household size in Turkey in 2020 was Şırnak with 5.75 people, followed by Şanlıurfa with 5.25 people [31]. Both provinces are located in the GAP region. The annual average equivalent household disposable income in Turkey was 33,428 TL (\$4761.8) in 2020. The average currency exchange rate for 2020 was $\$ 1=7.02 \mathrm{TL}$ [32]. The highest share of total income was composed of salary and wage income at $47.1 \%$, social transfer income at $21.8 \%$, and finally entrepreneur income at $17.7 \%$. The share of agricultural income of the entrepreneurial income was $20.9 \%$. According to the sectoral breakdown of main business incomes, the lowest annual average income was in the agriculture sector at 25,263 TL (\$3598.72) [33]. While $7.11 \%$ of equivalent household disposable income in Turkey consisted of agricultural entrepreneurial income in 2006, this rate decreased to $3.68 \%$ in 2020 [34]. Individuals who have income below a certain limit according to the general level of society are considered relatively poor. The poverty rate in Turkey was $15 \%$ according to the poverty line determined by considering $50 \%$ of the equivalent household disposable median income in 2020 . According to the poverty line determined by considering $60 \%$ of the median income, the poverty rate was $21.9 \%$ [33]. The lowest annual average equivalent household disposable income in 2020 was in the Eastern Anatolia Region, followed by the Southeastern Anatolia Region [35]. Food expenditure in Turkey, which was 2.5 billion TL in 2002, increased approximately 10 times and reached 23 billion TL in 2019. According to the combined results of the Household Budget Survey for 2017, 2018, and 2019, the majority of household consumption expenditure consisted of housing and rent, food and non-alcoholic beverages, and transportation. The region with the highest share of food expenditure out of household consumption expenditure was the TRB (Middle Eastern Anatolia) region at $28.5 \%$. The TRC (Southeastern Anatolia) region was the second-highest region at 26.5\% [36]. The TRB and TRC regions both have rural characteristics in terms of vitality, and their economies and culture consist of agricultural activities. In other words, these regions are poor regions and they spend a significant part of their income on nutrition. 
The agricultural area of Turkey, which was 40.9 million hectares (ha) in 2001, excluding meadow and pasture lands, decreased by $8.5 \%$ to 37.7 million ha in 2020 . In the same period, the cultivation areas of field crops decreased by $14.7 \%$ [37]. Additionally, a total of 3.5 million TL agricultural support payments made by the state to farmers in 2009 under various headings, which increased to 11.5 million TL in 2020 [38]. However, there has been a significant decrease in the number of farmers in the agricultural sector. For instance, the number of farmers registered with the Social Security Institution was 1,016,692 in 2009, which decreased by almost half to 547,075 people by the end of 2020 [39]. Moreover, the number of farmers who quit their agricultural activities, together with those who are not registered with the Social Security Institution, was around 2 million people [40]. This situation has made Turkey, which was one of the largest exporting and self-sufficient countries in terms of agricultural production in the world, an importer of agricultural products. According to the seasonally adjusted employment data from the Turkish Statistical Institute, 5.2 million people were employed in the agricultural sector in 2014 , which decreased to 4.9 million in 2021 [41]. In other words, there significant decreases occurred in both the number of farmers and those employed in agriculture.

Job and life satisfaction, which relates to the development and socioeconomic characteristics of rural areas, is a macroeconomic indicator that has been studied by many [42]. In addition to providing returns to employees, business life causes satisfaction based on the adequacy of income, expectations, and working conditions [43]. Although job satisfaction is personal and differs according to individuals, it is shaped by the work of the employees and the work environment [44]. Job satisfaction is the sum of the experiences and emotional reactions of the employees related to the work they do; it is a key component of life satisfaction, and when integrated properly it helps a person make sense of themselves and form a whole [43]. Happiness is one of the most important subjective values and is associated with pleasure, optimism, and hope. Happiness is an internal state that emerges based on human judgment, expectations, and lived experiences and has a situational nature $[45,46]$. Recently, there has been a great decrease in the rural population in Turkey, and migrations have caused increases and problems in the urban population. Individuals who are producers in rural areas have become consumers in urban life [47].

For this reason, it is necessary to investigate the satisfaction level of those living in rural areas to ensure the sustainability of agricultural production and to keep farmers from breaking away from agriculture. This study aims to analyze the satisfaction levels of farmers in different irrigation areas in the Southeastern Anatolia Project (GAP)-Şanliurfa, based on certain indicators related to agricultural production and influencing factors.

\section{Materials and Methods}

\subsection{Study Area}

It has been determined that the rural social structure is generally fatalistic and conservative and has region-specific norm values in social relations. In Turkey, it is also a life that is not very open to the outside, dealing with subsistence agriculture, low income, and low education levels [48]. The research area has a complex and traditional structure with a patriarchal culture, strong tribal ties, and varied production relations (property ownership, renting, partnerships, gravity versus pressurized irrigations, etc.). The GAP project is Turkey's most important multisectoral regional development project and is conducted in the Southeastern Anatolia Region, the country's second least developed region [6,49]. The GAP region is located in Upper Mesopotamia, which is one of the most important cradles of civilization in human history. The region is an important center in terms of its rich historical and cultural heritage, monotheistic beliefs, and gastronomy due to regional flavors and dishes [50]. Furthermore, there are also original handicrafts specific to the region that are about to disappear. The research area is quite suitable for development and 
raising the standard of living, not only due to its water and soil resources but also through its cultural values. Cultural heritage and rural tourism could function as tools for rural development and welfare, taking into account specific regional values and potentials with an appropriate strategy [51], thereby adding economic and social benefits [52].

The main purpose of the GAP is to increase the welfare level of the region by using the water and soil resources through agriculture and agriculture-based industry to increase income and subsequently improve the social and economic structures. Another goal is to reduce migration to cities by increasing productivity and employment opportunities in rural areas and to contribute to national goals such as economic growth and social stability through the effective use of resources [49]. The project area covers approximately $11 \%$ of Turkey, both in terms of area and population, and is envisaged to irrigate 1.86 million ha of agricultural land, with 22 dams within the scope of the project [53]. Şanliurfa has the most important agricultural potential of the region and the largest population, with 2.155 million people among the 9 provinces within the scope of the GAP [54]. The main livelihood of the people of Şanlıurfa is agriculture and agriculture-based industry; it has 1.06 million ha of agricultural land and approximately 2.5 million livestock [55]. Irrigation in Şanlıurfa within the scope of GAP started in 1994 in the Harran Plain, and by the end of 2019 irrigated agriculture, including public irrigation, was conducted over an area of approximately 482,000 ha [56]. The locations of GAP and Şanliurfa within Turkey are given in Figure 1. Today, together with the Upper Harran Plain, approximately 166,000 ha of land is under irrigation, with $85 \%$ gravity and $15 \%$ pressure in the Harran Plain of Şanliurfa [11,57]. The dominant product in the Harran Plain is cotton, followed by wheat and corn. Irrigation started in 2006, and pressurized irrigation is conducted over an area of approximately 22,000 ha in Yaylak. The dominant agricultural production consists of cotton, fruit trees (pistachio, almond, and grape), and vegetables. The Şanlıurfa-Harran Plain and Yaylak irrigation areas are shown in Figure 2.

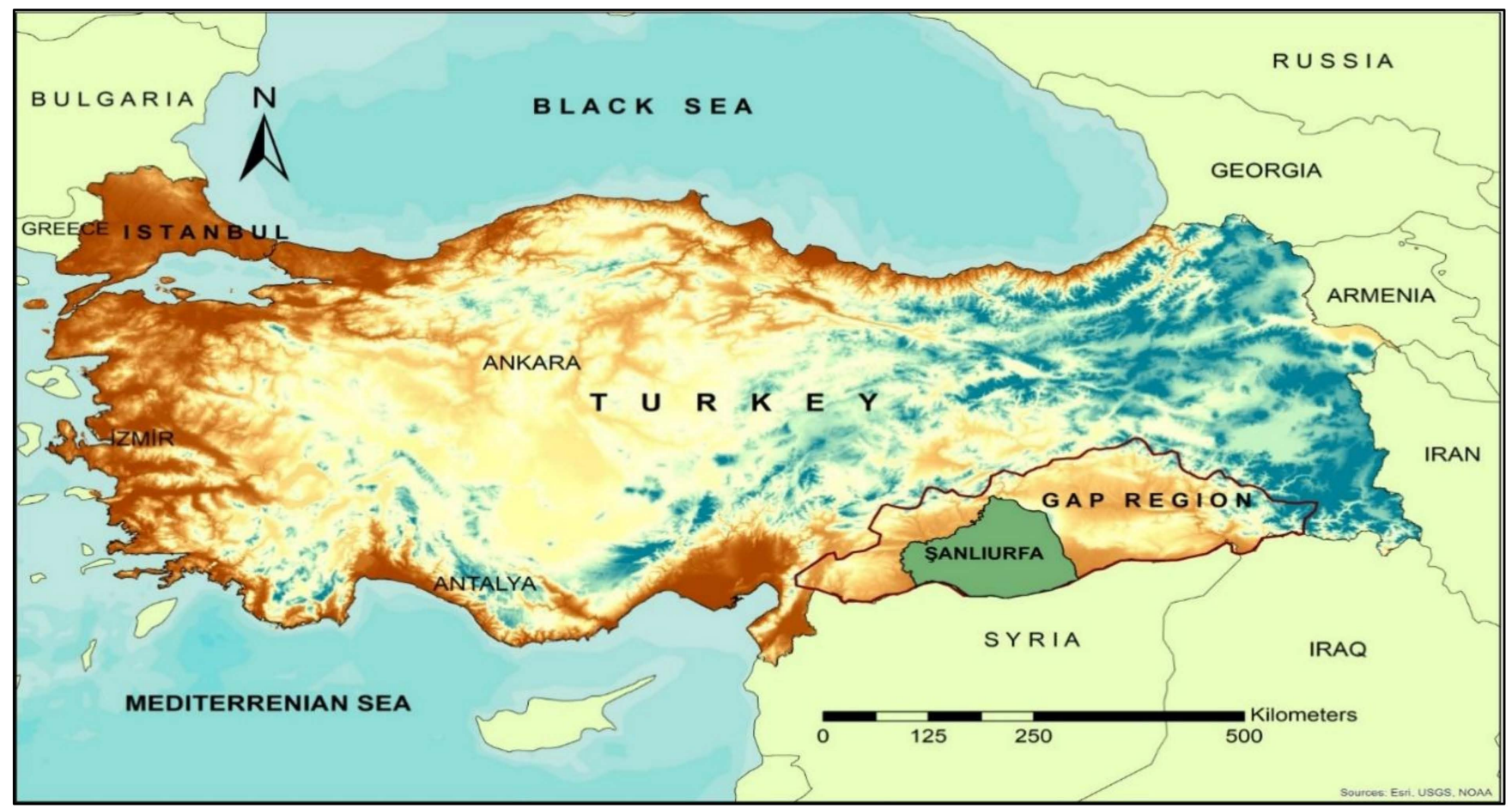

Figure 1. The locations of Turkey, GAP, and Şanlıurfa. 


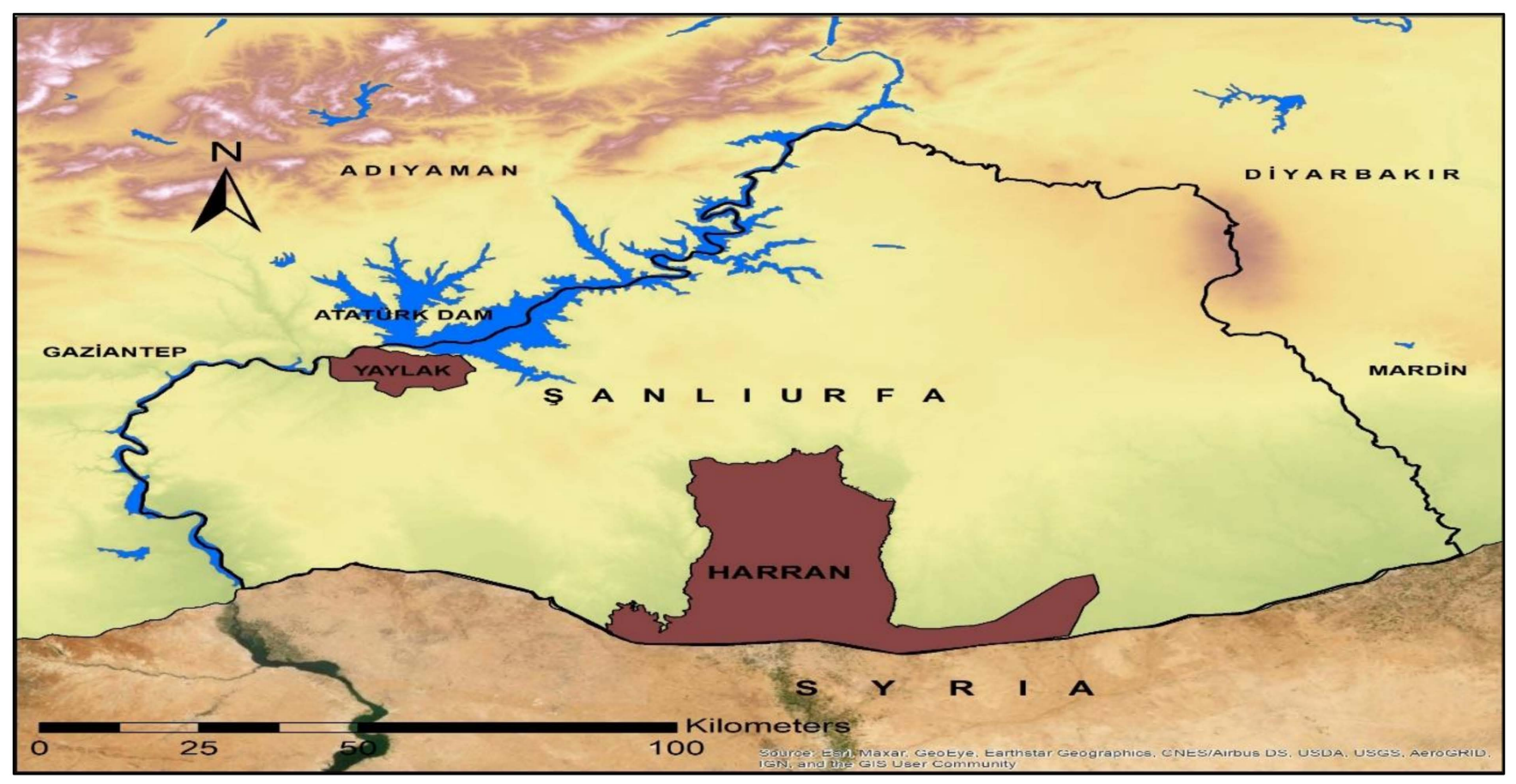

Figure 2. The locations of the Şanlıurfa-Harran Plain and Yaylak irrigation areas.

\subsection{Data Sources, Survey Design, and Statistical Methods}

The main research information was the primary data obtained from farmers in the Harran Plain and Yaylak irrigation areas. The ethics committee approval and permission number of the study were obtained from Harran University Social and Human Sciences Ethics Committee (E-76244175-752.01.01-37010). The data used in this research were obtained through face-to-face surveys with farmers selected using a simple random sampling method in 2020. The number of farmers registered in the farmer registration system in Şanliurfa was 59,862 in 2019, of which 15,824 were in the Harran Plain and 3180 were in the Yaylak irrigation area; thus, the number of registered farmers in the main sample in the research area was 19,004. The research sampling volume was found at the $95 \%$ confidence limit, with a $5 \%$ margin of error by using the table of sample volumes according to population size and tolerable sampling error [58], which was 377, with 432 used in analysis to be on the safe side.

The primary data obtained from the survey were analyzed with logistic regression in STATA via Excel, and the main purpose was to model the relationship between the categorical dependent variable (Are you happy to be a farmer?) and the independent variables (which can be categorical, continuous, or a combination of both). Logistic regression, also called a logit model, is defined by a response variable that can take on only one of two values, typically 1 and 0 , which are often interpreted as yes or no [59]. When a dependent variable regression model that takes 0 and 1 values is estimated with least squares, it is made with the maximum likelihood estimation method, since many problems are encountered, such as the non-normal distribution of the residues, changing variance, and the loss of the meaning of the determination coefficient $\mathrm{R}^{2}$. In the logit model, assumptions such as the normal distribution of residuals, constant error variance, and linearity are not sought [60]. The dependent variable in the logit model is theoretically the natural logarithm of the odds ratio. The probability of an event occurring divided by the probability of not occurring $(\mathrm{Pi} /(1-\mathrm{Pi}))$ is known as the odds ratio. The dependent variable in question takes the value of 1 if the event of interest occurs, otherwise it is 0 . As a result, in logit regression, the dependent variable is $\mathrm{Ln}(\mathrm{Pi} /(1-\mathrm{Pi}))$, with $\mathrm{Pi}$ being the probability of 
occurrence, which is called the logit function $[60,61]$. The logistic regression model is given in Equation (1) [61].

$$
\pi(\mathrm{x})=\frac{\mathrm{e}^{\beta_{0}+\beta_{1} \mathrm{x}}}{1+\mathrm{e}^{\beta_{0}+\beta_{1} \mathrm{x}}}
$$

The equation in terms of $\pi(x)$ is expressed by Equation (2), where the logit transformation that defines $\pi(\mathrm{x})$ between $-\infty$ and $+\infty$ in the equation given by (1) is applied [61].

$$
\mathrm{g}(\mathrm{x})=\ln \left[\frac{\pi(x)}{1-\pi(x)}\right]=\beta_{0}+\beta_{1} x
$$

This transformation, called logit, is denoted by $\mathrm{g}(\mathrm{x})$. The function $\mathrm{g}(\mathrm{x})$, which is linear in its parameters, can be continuous and lies in the range of $-\infty$ to $+\infty$, depending on the independent variable values.

\subsection{Uncertainties and Shortcomings}

The terms happiness, utility, life satisfaction, and well-being are interchangeable [62]. Happiness is used as a positive evaluation of one's life as a whole [63]. Happiness is a relatively subjective concept with different meanings but can be interpreted as a state of complete fulfillment and well-being. Some have considered happiness to be in the material field, some in the spiritual field, and some as a spiritual state that can be acquired in both material and spiritual fields [64]. Happiness is shaped according to expectations depending on work, life, family, and social structure. In this research, the happiness of the farmers was measured in terms of agricultural production-based material indicators, farming job satisfaction, and income. Job satisfaction and income may vary from year to year depending on production quantities and prices. Farmers who were happy in the previous production seasons may be unhappy in the next production season. The opposite is also possible. On the other hand, the authors acknowledge that many farmers living in the countryside depend on subsistence agriculture and have a low income. However, they also live according to the social dynamics of the geographical regions and tend to have high moral values. Furthermore, living away from the crowds and being intertwined with nature can contribute to feeling happy.

The variables used in the analysis were chosen in accordance with the sociocultural structure of the research area. Many factors affect the happiness of farmers; social, environmental, and cultural elements and spiritual values including beliefs and lifestyle are some of them. The research area has a social structure with strong patriarchal, feudal, and tribal ties, which is not often seen in other parts of the country. Additionally, the majority of the inhabitants have a conservative and fatalistic lifestyle, and sect, religious (sheikhdom), and opinion leaders are the final decision-makers, are still common in the research area. Although this structure and organizational form, which is centuries old, has started to change over time, it still continues to be effective. This situation emerged as a result of the sociocultural structure for reasons such as tradition, belonging, security, existence, and effectiveness, rather than individual or group preferences. Asking questions about these concepts is mostly not welcomed in the region and realistic answers cannot be obtained. Local individuals are prejudiced against researchers and mostly refuse to participate in such surveys. On the other hand, the factors relating to the physical environment show a very large degree of homogeneity in the research area. For these reasons, concepts such as social and environmental beliefs were not taken as variables.

\section{Results and Discussion}

\subsection{The Descriptive Statistics of the Surveyed Farmers}

Women play important and active roles in agricultural production processes and activities in the region where the research was conducted. However, due to the existing social dynamics in the region, its unique cultural values, and the fact that the last decisionmakers in the households are men, it was necessary to conduct all interviews with male 
farmers $[6,18,25,65-67]$. For the same reasons, only male farmers were interviewed in the research area. Here, $99.5 \%$ of the farmers participating in the survey were married and the average age was 48.92 years. The average household participation in the workforce was 3.04 people, of which the number of people working in agriculture was 2.71 and the number of people working outside of agriculture was 0.27 . The average household income was $5689.1 \mathrm{TL} /$ ha $(\$ 810.41 / \mathrm{ha})$. The descriptive statistics for the farmers participating in the research are given in Table 1.

Table 1. Descriptive statistics of the surveyed farmers.

\begin{tabular}{|c|c|c|c|}
\hline Dependent Variable & Definition & Mean & Standard Deviation \\
\hline Are you happy to be a farmer? & 0 for No $(56.7 \%), 1$ for Yes $(43.3 \%)$ & 0.43 & 0.496 \\
\hline Independent Variables & Definition & Mean & Standard Deviation \\
\hline Location of Irrigation Area & $\begin{array}{l}1 \text { for Harran Plain }(71.0 \%), 2 \text { for Yaylak } \\
\qquad(29.0 \%)\end{array}$ & 1.29 & 0.021 \\
\hline Level of Education & $\begin{array}{c}1 \text { for illiterate }(4.7 \%), 2 \text { for literate }(15.5 \%), \\
3 \text { for primary school }(46.1 \%), 4 \text { for } \\
\text { secondary school }(15.0 \%), 5 \text { for high } \\
\text { school }(14.8 \%), 6 \text { for University }(4.0 \%)\end{array}$ & 3.31 & 0.056 \\
\hline Non-farming income & 0 for No $(72.0 \%), 1$ for Yes $(28.0 \%)$ & 0.28 & 0.450 \\
\hline Livestock & 0 for No $(32.6 \%), 1$ for Yes $(67.4 \%)$ & 0.67 & 0.469 \\
\hline Income (TL/year) & Minimum 10,000, Maximum 600,000 & $73,957.87$ & $55,538.803$ \\
\hline Farming Experience (year) & Minimum: 2, Maximum: 63 & 31.84 & 9.905 \\
\hline Household Number (person) & Minimum: 2, Maximum: 20 & 8.64 & 2.830 \\
\hline Amount of Land Cultivated (ha) & Minimum: 1, Maximum: 120 & 13.0 & 12.84 \\
\hline
\end{tabular}

Of the surveyed farmers, $43.3 \%$ were happy to be farmers in the current situation. The happiness rate was measured at $38.24 \%$ in a study of cocoa producers in Trinidad and Tobago [68], while in studies of Vietnam the rates were 62.5\% for aquaculture farmers [69] and $52 \%$ for those living in rural areas [70].

Here, $93.5 \%$ of the survey participants were members of an organized Chamber of Agriculture and Irrigation Association. However, based on this result, it is not correct to conclude that the farmers in the research area are successful at organizing themselves. These memberships are mandatory, with the membership of the Chamber of Agriculture necessary to benefit from agricultural support and membership in the Irrigation Association required to benefit from agricultural irrigation. The rate of those who were members of a truly organized structure such as producer unions and agricultural cooperatives among the survey participants was $12.04 \%$. Not being able to organize agricultural activities is a problem for various reasons in the research area [67]. Effective organization of farmers is an important tool in increasing the welfare level in rural areas due to the positive results from such activities, such as agricultural sustainability and income increase [67].

Furthermore, $63.2 \%$ of the farmers chose pesticide, fertilizer, and seed dealers as sources of information for agricultural production. In other words, agricultural consultancy services have not developed enough in the research field. Commercial enterprises, which are seen as a source of information, are those that sell agricultural input products, and their main purpose is to gain profit, not productivity. On the other hand, excessive use of chemicals poses significant hazards and risks in terms of human and environmental health [71]. Excessive and uncontrolled human activities in the environment increase these problems and gradually destroy the habitable environment in rural areas [72]. The formation of income in agricultural production begins with the supply of inputs. Although agricultural product selling prices are low, profits can still be made if qualified input 
costs are low. For the inputs to be of high quality and economical, an organized farmers' structure and effective consultancy services are needed.

The following questions, which may affect the agricultural production activities and incomes of the farmers, were asked and the answers received are given in Table 2. According to the results, $27.5 \%$ of the farmers who participated in the survey were satisfied with the public product support system and the amounts given, $41.9 \%$ did not experience financial difficulties in the agricultural production process, $48.4 \%$ could easily access agricultural finance and credit when they needed it, $15.7 \%$ were satisfied with the market selling price of the agricultural products they have produced, $31.7 \%$ did not have any problems in marketing the agricultural products they produced, and $43.5 \%$ considered effective organizations (cooperatives, unions, extension services, etc.,) necessary to live well in rural areas.

Table 2. Farmers' statements regarding agricultural production activities.

\begin{tabular}{|c|c|c|c|c|}
\hline \multicolumn{5}{|c|}{ I Am Satisfied with the Public Product Support System and the Amounts Given } \\
\hline Participation Level & Frequency & Percent & Mean & Standard Deviation \\
\hline No & 164 & 38.0 & \multirow{4}{*}{1.90} & \multirow{4}{*}{0.804} \\
\hline Partially & 149 & 34.5 & & \\
\hline Yes & 119 & 27.5 & & \\
\hline Total & 432 & 100.0 & & \\
\hline \multicolumn{5}{|c|}{ I do not experience financial difficulties in the agricultural production process } \\
\hline Participation Level & Frequency & Percent & Mean & Standard Deviation \\
\hline No & 90 & 20.8 & \multirow{4}{*}{2.21} & \multirow{4}{*}{0.764} \\
\hline Partially & 161 & 37.3 & & \\
\hline Yes & 181 & 41.9 & & \\
\hline Total & 432 & 100.0 & & \\
\hline \multicolumn{5}{|c|}{ I can easily access agricultural finance and credit when I need it } \\
\hline Participation Level & Frequency & Percent & Mean & Standard Deviation \\
\hline No & 112 & 25.9 & \multirow{4}{*}{2.22} & \multirow{4}{*}{0.833} \\
\hline Partially & 111 & 25.7 & & \\
\hline Yes & 209 & 48.4 & & \\
\hline Total & 432 & 100.0 & & \\
\hline \multicolumn{5}{|c|}{ I am satisfied with the market selling prices of the agricultural products I have produce } \\
\hline Participation Level & Frequency & Percent & Mean & Standard Deviation \\
\hline No & 235 & 54.4 & \multirow{4}{*}{1.61} & \multirow{4}{*}{0.744} \\
\hline Partially & 129 & 29.9 & & \\
\hline Yes & 68 & 15.7 & & \\
\hline Total & 432 & 100.0 & & \\
\hline \multicolumn{5}{|c|}{ I do not have any problems in marketing the agricultural products I produce } \\
\hline Participation Level & Frequency & Percent & Mean & Standard Deviation \\
\hline No & 166 & 38.4 & \multirow{4}{*}{1.93} & \multirow{4}{*}{0.836} \\
\hline Partially & 129 & 29.9 & & \\
\hline Yes & 137 & 31.7 & & \\
\hline Total & 432 & 100.0 & & \\
\hline
\end{tabular}

Effective organizations such as cooperatives, unions, and extension services are necessary to live well in rural areas

\begin{tabular}{ccccc}
\hline Participation Level & Frequency & Percent & Mean & Standard Deviation \\
\hline No & 95 & 22.0 & & \\
Partially & 149 & 34.5 & 2.22 & 0.781 \\
Yes & 188 & 43.5 & & \\
Total & 432 & 100.0 & & \\
\hline
\end{tabular}


These results show that more public agricultural supports, organized structures, and effective agricultural extension activities are needed to ensure the income, welfare, and happiness of the farmers. Agricultural extension has critical importance in terms of welfare due to the changes and conditions in agricultural production, as well as social and political factors associated with rural development [73]. There is a need for information and services that will increase production and happiness levels, as well as public financial support for agricultural production, which will hell in adapting to changing conditions and in the development of the socioeconomic structure in rural areas [74,75]. In a study conducted in the research area, it was determined that farmers are willing to pay for an effective agricultural extension and consultancy service that will bring more income [76].

\subsection{Results of the Model}

The results of the model are given in Table 3. First, the likelihood ratio chi-square statistic was calculated as 41.29 and $p=0.000$. According to this result, it is possible to say that the model is significant at the error level of 0.01 and the pseudo $R^{2}$ is calculated as 0.070. In logit regression, assumptions need to be tested after the model estimation is made. First, the correlation matrix of continuous independent variables is checked to see whether there is a multicollinearity problem. It was observed that all correlation values in the matrix were below 0.50 . For this reason, it was concluded that the multicollinearity problem will not occur. The link test was applied for the model specification assumption, which is another assumption test. As a result of the link test, it was determined that the coefficient of the variable "_hatsq" in the output was statistically insignificant (coefficient $=-0.034$, $p=0.833$ ). According to this result, it was concluded that there was no model specification error in the model. Finally, the Hosmer and Lemeshow goodness-of-fit test result was ( $p=0.338)$, showing that the model-data fit was sufficient.

Table 3. The model results.

\begin{tabular}{ccc}
\hline \multicolumn{2}{c}{ Dependent Variable: Are You Happy to Be a Farmer $\mathbf{( 0 =}$ No, $\mathbf{1}=$ Yes) } \\
\hline Independent Variables & $\begin{array}{c}\text { Coefficient } \\
\text { (Standard Error) }\end{array}$ & $\begin{array}{c}\text { Odds Ratio } \\
\text { (Standard Error) }\end{array}$ \\
\hline Location of Irrigation Area & $-0.586^{* *}$ & $0.557^{* *}$ \\
Yaylak Region & $(0.258)$ & $(0.143)$ \\
\hline Level of Education & $1.450^{* *}$ & \\
Literate & $(0.566)$ & $4.263^{* *}$ \\
Primary school & $1.022^{*}$ & $(2.413)$ \\
Secondary school & $(0.548)$ & $2.780^{*}$ \\
High school & $1.014^{*}$ & $(1.524)$ \\
University & $(0.614)$ & $\left(1.758^{*}\right.$ \\
& 0.716 & 2.046 \\
& $(0.631)$ & 1.291 \\
Yes & 0.970 & $(2.039$ \\
& $(0.795)$ & 1.017 \\
Non-farming Income & & $(0.244)$ \\
\hline Livestock & 0.017 & 1.154 \\
Yes & $(0.240)$ & $(0.270)$ \\
\hline Income (TL/year) & 0.143 & $1.000007^{* * *}$ \\
& $(0.234)$ & $\left(2.5 \times 10^{-6}\right)$ \\
\hline
\end{tabular}


Table 3. Cont.

\begin{tabular}{ccc}
\hline \multicolumn{2}{c}{ Dependent Variable: Are You Happy to Be a Farmer $\mathbf{( 0 = \mathbf { N o } , \mathbf { 1 } = \text { Yes) }}$} \\
\hline Independent Variables & $\begin{array}{c}\text { Coefficient } \\
\text { (Standard Error) }\end{array}$ & $\begin{array}{c}\text { Odds Ratio } \\
\text { (Standard Error) }\end{array}$ \\
\hline \multirow{2}{*}{ Farming Experience (year) } & $0.035^{* *}$ & $1.035^{* *}$ \\
& $(0.013)$ & 0.014 \\
\hline \multirow{2}{*}{ Household Number (person) } & -0.008 & 0.992 \\
& $(0.046)$ & $(0.045)$ \\
\hline \multirow{2}{*}{ Amount of Land Cultivated (ha) } & $3.4 \times 10^{-4}$ & 1.00034 \\
& $\left(9.5 \times 10^{-4}\right)$ & $\left(9.5 \times 10^{-4}\right)$ \\
\hline
\end{tabular}

1. $N=432$, LR Chi-square $=41.29(p=0.000)$, Pseudo $\mathrm{R}^{2}=0.070 .2$. Link test: hatsq $=-0.034, p=0.833$. 3. Level of importance: ${ }^{* *} p<0.01,{ }^{* *} p<0.05,{ }^{*} p<0.1$. 4. The basic level for the irrigation area variable is "Harran", the basic level for the education variable is "Illiterate", the basic level for the non-farming income variable is "No", for the livestock variable the basic level is "No".

\subsection{Discussions Based on the Model Results}

According to the results in Table 3, the coefficient of the Yaylak irrigation area in the irrigation area location variable was calculated as -0.586 . This coefficient is negative and statistically significant $(p=0.023<0.05)$. Accordingly, the probability of being happy for the farmers in the Yaylak region is lower than it is for the farmers in the Harran region, which is the basic level. Because of pressurized irrigation in Yaylak, even if all input costs in agricultural production are the same as in the Harran Plain where gravity irrigation is applied, farmers pay approximately 2.5 times more in irrigation fees. This situation directly affects the income of the farmers, and consequently their welfare.

Statistically positive and significant results were obtained for education levels of literate $($ coefficient $=1.450, p=0.010<0.05)$, primary school $($ coefficient $=1.022, p=0.062<0.10)$, and secondary school (coefficient $=1.014, p=0.099<0.10$ ) for the education variable. According to these results, it is possible to say that the probability of being happy is higher for farmers who are literate and have primary and secondary school educations compared to the illiterate farmers, which is the basic level. The difference was not statistically significant for high school and university graduates. In the research area, the level of education in rural areas is low, and the average time spent in education was calculated as 6.06 years, which is between primary and secondary school graduates. On the other hand, as the level of education increases, individuals tend to prefer cities as living spaces instead of rural areas. In a study on the happiness and life satisfaction of aquaculture growers in South Vietnam, it was found that a large portion of the respondents had high levels of education. In the research, it was stated that more than $75 \%$ of the farmers had a secondary or higher education level, so they were more willing to adopt new agricultural technologies, making it easier for them to access information and improve their welfare level [69]. In a study conducted in Senegal, it was determined that the education level of farmers had a positive effect on their declared happiness levels [77]. In a study conducted in China, it was determined that the average education level of the farmers was primary and secondary, and it was suggested that the increase in education level increased the rural satisfaction of the farmers [78]. In studies conducted in India, Ghana, Turkey, West Asia, and Ethiopia, it has been determined that the education level of farmers in agricultural production affects their productivity and income, and consequently their standard of living [76,79-83].

In the analyses, it was determined that non-agricultural income was not a statistically significant factor in farmer happiness in terms of agricultural activities $(p>0.10)$. During the field interviews, the farmers stated that they mostly used their income from nonagricultural activities to finance their agricultural activities. This situation does not create happiness for farmers if the return amount and speed of non-agricultural financing invested in agriculture is below expectations. In the study Participation in the "Modern Agro-Food Supply Chain and Happiness" in rural areas in Senegal, it was determined that income and indirect income were not effective factors [77]. On the other hand, in the rural life 
studies conducted in Ethiopia, Ghana, Pakistan, and Vietnam, it was determined that non-agricultural income is an effective factor in rural household life satisfaction levels, the fight against poverty, food consumption, agricultural production, and income [84-87].

The effect of livestock activities on the happiness of being a farmer is not statistically significant. During the field interviews, the farmers complained about the high cost of feed and stated that they had experienced losses in animal production recently. In a study conducted in the research area, it was determined that approximately $70 \%$ of livestock expenses are composed of feed costs [88]. In a study conducted for the FAO, it was stated that livestock represent an important component of the agricultural economy and are a driving force in food security, the fight against rural poverty, economic stability, and sustainable development [89]. In a study on the effects of contract farming on farmer happiness in Senegal, it was determined that animal husbandry is an effective factor in happiness [77].

The coefficient of the income variable was calculated as 0.000007 . This coefficient is positive and statistically significant $(p=0.004<0.01)$. Accordingly, it is possible to say that the probability of being happy increases as income increases. In academic studies, it has been determined that there is a very strong relationship in the same direction between the individual or household income and happiness level. The income variable is one of the most used pieces of data to explain the level of happiness [70,90-92]. In studies on the happiness level of farmers producing different products in many different fields, it was determined that there is a positive and strong relationship between income and happiness level $[46,69,70,77,78]$. In a study covering nine European countries, it was determined that a strong farm financial structure increases the happiness of the farmer [93]. Similar results were found for paddy producer farmers in Malaysia [94].

The coefficient of the farming experience variable was calculated as 0.035 . This coefficient is positive and statistically significant $(p=0.010<0.05)$. It is possible to say that as the experience increases, the probability of the farmer being happy also increases. Experience emerges when struggling with problems and life expectancy, depending on age and experiences. Experienced farmers can solve their production-based problems more easily and set their expectations realistically so that they can live happily with what they have. According to the World Values Survey data, it has been revealed that older people are happier than younger people [95]. A similar situation is valid for the elderly who are engaged in agricultural activities and live in rural areas. In studies conducted with cocoa producers in Trinidad and Tobago and aquaculture growers in South Vietnam, it was determined that older farmers have higher levels of happiness and life satisfaction than younger farmers have in agricultural activities [68,69].

For the household variable, as the number increases, happiness decreases, and the coefficient of the variable is negative. However, this result is not statistically significant. This result is interpreted as a concern for livelihoods in crowded families in rural areas. In a study conducted in Trinidad and Tobago, it was determined that the low number of households increased happiness [68]. On the other hand, in the study conducted in Senegal, it was determined that the demographic characteristics of the household (a high number of adults) affected happiness [77].

The amount of cultivated land variable is not statistically significant regarding farmer happiness. As the amount of land increased, it was expected that income would increase, and consequently happiness would increase. However, there was a loss of income in agricultural production recently due to the increased input costs and fluctuations in product sale prices in the research area. In the study conducted in Senegal, it was determined that the amount of land affected happiness [77]. Similarly, it was determined that the amount of land was an effective factor in the study of happiness and farm yield among corn producers in China [78].

The farmers who participated in the survey were asked whether they wanted their children to become farmers and continue agricultural activities, with their answers given in Table 4. 
Table 4. Do farmers want their children to be a farmer and continue agricultural activities?

\begin{tabular}{ccccc}
\hline \multicolumn{5}{c}{ I Want My Children Also to do Farming Activities and Continue Farming after Me } \\
\hline Participation Level & Frequency & Percent & Mean & Standard Deviation \\
\hline No & 183 & 42.4 & & \\
Partially & 95 & 22.0 & 1.93 & 0.882 \\
Yes & 154 & 35.6 & & \\
Total & 432 & 100.0 & & \\
\hline
\end{tabular}

While those with higher incomes, land amounts, and experience, along with livestock breeders, expressed their opinion that their children should continue farming, as the number of households increased, those in the Yaylak irrigation area and those with nonagricultural income expressed their opinion that their children should not continue farming.

\section{Conclusions}

Firstly, agricultural production, which is mostly conducted in rural areas where work and family life are a whole, is a vital issue in terms of food safety. Generally, the income and welfare levels are lower in rural areas than in the cities, and poverty is the most important problem in the lives of those who practice subsistence agriculture. Where and for what reasons the poverty is concentrated, as well as the degree of poverty, are important issues. The most poverty in Turkey is seen in the Eastern Anatolia and Southeastern Anatolia Regions, where farming is the main source of livelihood.

Here, $43.3 \%$ of the surveyed farmers are happy to be farmers in the current situation, with the area of irrigation, education level, income, and farming experience being statistically significant at different rates in their happiness. To increase the happiness of being a farmer, special attention should be given to these factors, which will also affect the degree of poverty resulting from the policies implemented by the public. Additionally, 35.6\% of farmers want their children to continue farming activities. There is a $7.7 \%$ difference between those who are happy to be a farmer and those who want their children to continue farming. People living in rural areas have an extended family structure and prefer their children to stay with them in the research area. The large family structure is a force against external threats and a source of unpaid labor for agricultural activities in rural areas. The difference between the two results is mainly due to their subsistence expectations, which indicates that there is insufficient income in the rural area.

Additional public policies are needed to raise the welfare in rural areas. These policies should include the participation of the private sector. The private sector conducts its activities based on profit. In agricultural activities and rural areas, the profit margins are low and the risk is high. Therefore, if the state provides some subsidies and support, the participation of the private sector will increase. Additionally, this participation could also be achieved within the scope of social responsibility initiatives. The primary way to increase welfare in rural areas is effective agricultural extension activities. In this regard, firstly the employees in the extension service should be qualified in terms of changing natural and climatic conditions and technological innovation. Afterward, it will be necessary to raise awareness of the farmers' problems through extension services, which must be in a way that the farmers can understand and must be based on demand.

On the other hand, it is also important to be aware of the potential profits related to the cultural values and rural tourism created by the farmers due to their rich history, culture, belief, gastronomy, and handicrafts, which will provide potential increases in welfare and happiness. To turn this potential into commercial profit, the participation of the private sector should be encouraged.

More detailed field studies are needed on the agricultural extension needs of the farmers and for their cultural values to be transformed into income. The public policies to be implemented based on the data to be obtained as a result of such detailed studies will increase the social and economic welfare in rural areas, thereby increasing the happiness of 
the farmers. This study was the first of its kind to be conducted in Turkey according to the literature review.

Author Contributions: Conceptualization, M.H.A., M.C., M.R.S., M.A.Ç., K.Y., N.K. and G.S.; methodology, M.H.A., M.C., M.R.S. and N.K.; software, M.H.A., M.C. and M.R.S.; validation, M.H.A., M.A.Ç., K.Y., N.K. and B.K.; formal analysis, M.H.A., M.C. and M.R.S.; investigation, M.H.A., M.A.Ç., K.Y., B.K., Ş.Ö., U.B., H.P.D., G.S. and Z.Ş.; resources, M.H.A., M.C., M.R.S., H.P.D., G.S. and Z.Ş.; data curation, M.H.A., M.C., M.R.S. and N.K.; writing-original draft preparation, M.H.A., M.C. and M.R.S.; writing-review and editing, M.H.A., M.C., M.R.S., K.Y., B.K., G.S. and Ş.Ö.; visualization, M.H.A., M.C. and M.R.S.; supervision, M.H.A., K.Y. and N.K.; project administration, M.H.A., K.Y. and N.K.; funding acquisition, N.M., C.K., A.Y. (Ayla Yenikale), and A.Y.(Akif Yenikale); All authors have read and agreed to the published version of the manuscript.

Funding: This research was funded by the "Republic of Turkey Ministry of Industry and Technology, Southeastern Anatolia Project (GAP) Regional Development Administration", grant number "27 September 2019/2033", together with Harran University.

Institutional Review Board Statement: The ethics committee approval and permission number of the study were obtained from Harran University Social and Human Sciences Ethics Committee (E-76244175-752.01.01-37010).

Informed Consent Statement: Voluntary participation approval was obtained from individuals who were surveyed face to face.

Data Availability Statement: Not applicable.

Conflicts of Interest: The authors declare no conflict of interest.

\section{References}

1. Boyles, J.G.; Cryan, P.M.; McCracken, G.F.; Kunz, T.H. Economic importance of bats in agriculture. Science 2011, 332, 41-42. [CrossRef] [PubMed]

2. Jones, A.D.; Ejeta, G. A new global agenda for nutrition and health: The importance of agriculture and food systems. Bull. World Health Organ. 2016, 94, 228-229. [CrossRef] [PubMed]

3. Aydoğdu, M.H.; Bilgiç, A. An evaluation of farmers' willingness to pay for efficient irrigation for sustainable usage of resources: The GAP-Harran Plain case, Turkey. J. Integr. Environ. Sci. 2016, 13, 175-186. [CrossRef]

4. Gillespie, S.; Van den Bold, M. Agriculture, food systems, and nutrition: Meeting the challenge. Glob. Chall. 2017, 1, 1600002. [CrossRef]

5. Sevinç, G.; Aydoğdu, M.H.; Cançelik, M.; Sevinç, M.R. Farmers' attitudes toward public support policy for sustainable agriculture in GAP-Şanlıurfa, Turkey. Sustainability 2019, 11, 6617. [CrossRef]

6. Doğan, H.P.; Aydoğdu, M.H.; Sevinç, M.R.; Cançelik, M. Farmers' willingness to pay for services to ensure sustainable agricultural income in the GAP-Harran Plain, Şanlıurfa, Turkey. Agriculture 2020, 10, 152. [CrossRef]

7. Norton, G.W.; Alwang, J.; Masters, W.A. Economics of Agricultural Development: World Food Systems and Resource Use, 4th ed.; Routledge: London, UK, 2021; ISBN 978-0-429-31699-9.

8. Reidsma, P.; Ewert, F.; Lansink, A.O.; Leemans, R. Adaptation to climate change and climate variability in European agriculture: The importance of farm level responses. Eur. J. Agron. 2010, 32, 91-102. [CrossRef]

9. Crane, T.A.; Roncoli, C.; Hoogenboom, G. Adaptation to climate change and climate variability: The importance of understanding agriculture as performance. NJAS Wagening. J. Life Sci. 2011, 57, 179-185. [CrossRef]

10. Aydoğdu, M.H.; Yenigün, K. Farmers' risk perception towards climate change: A case of the GAP-Şanlıurfa Region, Turkey. Sustainability 2016, 8, 806. [CrossRef]

11. Aydoğdu, M.H. Farmer's risk perception and willingness to pay for environment: Case study of GAP-Sanliurfa, Turkey. Fresenius Environ. Bull. 2016, 25, 5449-5455.

12. Zhang, P.; Zhang, J.; Chen, M. Economic impacts of climate change on agriculture: The importance of additional climatic variables other than temperature and precipitation. J. Environ. Econ. Manag. 2017, 83, 8-31. [CrossRef]

13. Falco, C.; Donzelli, F.; Olper, A. Climate change, agriculture and migration: A Survey. Sustainability 2018, 10, 1405. [CrossRef]

14. Dottori, F.; Szewczyk, W.; Ciscar, J.-C.; Zhao, F.; Alfieri, L.; Hirabayashi, Y.; Bianchi, A.; Mongelli, I.; Frieler, K.; Betts, R.A.; et al. Increased human and economic losses from river flooding with anthropogenic warming. Nat. Clim. Chang. 2018, 8, 781-786. [CrossRef]

15. Aydoğdu, M.H. Farmers' attitudes to the pricing of natural resources for sustainability: GAP-Şanllurfa Sampling of Turkey. Water 2019, 11, 1772. [CrossRef]

16. Aggarwal, P.; Vyas, S.; Thornton, P.; Campbell, B.M.; Kropff, M. Importance of considering technology growth in impact assessments of climate change on agriculture. Glob. Food Secur. 2019, 23, 41-48. [CrossRef] 
17. Aydoğdu, M.H.; Kaya, F. Factors affecting consumers' consumption of organic foods: A case study in GAP-Şanliurfa in Turkey. J. Agric. Sci. Technol. 2020, 22, 347-359.

18. Aydoğdu, M.H.; Sevinç, M.R.; Cançelik, M. Determination of farmers' willingness to pay for drought adaptation policies in Şanlıurfa, Turkey. Weather Clim. Soc. 2021, 13, 677-686. [CrossRef]

19. Aydoğdu, M.H.; Cançelik, M.; Sevinç, M.R.; Çullu, M.A.; Yenigün, K.; Küçük, N.; Karlı, B.; Ökten, Ş.; Beyazgül, U.; Doğan, H.P.; et al. Is drought caused by fate? Analysis of farmers' perception and its influencing factors in the irrigation areas of GAP-Şanliurfa, Turkey. Water 2021, 13, 2519. [CrossRef]

20. Savari, M.; Abdeshahi, A.; Gharechaee, H.; Nasrollahian, O. Explaining farmers' response to water crisis through theory of the norm activation model: Evidence from Iran. Int. J. Disaster Risk Reduct. 2021, 60, 102284. [CrossRef]

21. Fischer, G.; Shah, M.; Tubiello, F.N.; Van Velhuizen, H. Socio-economic and climate change impacts on agriculture: An integrated assessment, 1990-2080. Philos. Trans. R. Soc. B Biol. Sci. 2005, 360, 2067-2083. [CrossRef]

22. Brinkman, M.L.J.; da Cunha, M.P.; Heijnen, S.; Wicke, B.; Guilhoto, J.J.M.; Walter, A.; Faaij, A.P.C.; van der Hilst, F. Interregional assessment of socio-economic effects of sugarcane ethanol production in Brazil. Renew. Sustain. Energy Rev. 2018, 88, 347-362. [CrossRef]

23. Mobolade, A.J.; Bunindro, N.; Sahoo, D.; Rajashekar, Y. Traditional methods of food grains preservation and storage in Nigeria and India. Ann. Agric. Sci. 2019, 64, 196-205. [CrossRef]

24. Topçu, Y. Effective factors' analysis on willingness to utilize from farmers' agricultural aupport policies: The case study of Erzurum province. Akdeniz Üniversitesi Ziraat Fakültesi Derg. 2008, 21, 205-212.

25. Aydoğdu, M.H.; Sevinç, M.R.; Cançelik, M.; Doğan, H.P.; Şahin, Z. Determination of farmers' willingness to pay for sustainable agricultural land use in the GAP-Harran Plain of Turkey. Land 2020, 9, 261. [CrossRef]

26. Öztürk, Ş. Rural poverty and neo-liberal economy policies. Uluslar. Sos. Araştırmalar Derg. 2008, 1, 605-634.

27. Yüceer, S.E.; Tan, S.; Semerci, A. Examining 2000-2020 periods of agricultural support policies in Turkey. ÇOMÜ LJAR 2020, 1 , 36-46.

28. Whitford, A.B.; Provost, C. Government promotion of corporate social responsibility: Evidence from the EU Eco-Management and Audit Scheme. Rev. Policy Res. 2019, 36, 28-49. [CrossRef]

29. Alemdar, T.; Demirdöğen, A.; Ören, M.N. Rural poverty, measurement issues and Turkey, 1st ed.; Selçuk University Publications: Konya, Turkey, 2012; pp. 322-329.

30. Karsan, A.; Karlı, B. An overview of rural poverty in Turkey: The case of Sütçüler district of Isparta province. Mustafa Kemal Üniversitesi Ziraat Fakültesi Derg. 2016, 21, 168-181.

31. TURKSTAT. Family with Statistics 2020. Available online: https:// data.tuik.gov.tr/Bulten/Index?p=Istatistiklerle-Aile-2020-372 51 (accessed on 17 October 2021).

32. Central Bank of the Turkish Republic Average Exchange Rate. Available online: https://www.tcmb.gov.tr/wps/wcm/connect/ EN/TCMB+EN/Main+Menu/Statistics/Exchange+Rates/Indicative+Exchange+Rates (accessed on 7 June 2021).

33. TURKSTAT. Income and Living Conditions Survey 2020. Available online: https:/ / data.tuik.gov.tr/Bulten/Index?p=Incomeand-Living-Conditions-Survey-2020-37404\#: \{\}:text=Buna\%20g\%C3\%B6re\%2C\%202020\%20y\%C4\%B11\%C4\%B1\%20anket, artarak $\% 20 \% 13 \% 2$ C7\%20ldu (accessed on 17 October 2020).

34. TURKSTAT. Distribution of Annual Household Disposable Income (Vertical, \%). Available online: https://biruni.tuik.gov.tr/ medas $/$ ?kn=65\&locale $=\operatorname{tr}$ (accessed on 17 October 2021).

35. TURKSTAT. Regional Results of Income and Living Conditions Survey 2020. Available online: https:/ / data.tuik.gov.tr/Bulten/ Index?p=Income-and-Living-Conditions-Survey-Regional-Results-2020-37405 (accessed on 17 October 2021).

36. TURKSTAT. Household Consumption Expenditure (Regional). 2019. Available online: https://data.tuik.gov.tr/Bulten/Index?p= Household-Consumption-Expenditures-(Regional)-2019-33594 (accessed on 17 October 2021).

37. TURKSTAT. Agricultural Fields, 2001-2020. Available online: https://data.tuik.gov.tr/Kategori/GetKategori?p=Tarim-111 (accessed on 17 October 2021).

38. Tarım ve Orman Bakanlığı. Crop Production Data. Available online: https://www.tarimorman.gov.tr/sgb/Belgeler/ SagMenuVeriler/BUGEM.pdf (accessed on 17 October 2021).

39. Sosyal Güvenlik Kurumu. Insured, Active, Total (Agriculture). Available online: https:/ /veri.sgk.gov.tr/ (accessed on 17 October 2020).

40. Ataseven, Y. Agricultural support policies in Turkey: Overview and current evaluations. Türkiye Ziraat Odaları Birliği Çiftçi Ve Kö Dünya. Derg. 2016, 375, 54-59.

41. TURKSTAT. Employed According to Seasonally Adjusted Economic Activity. Available online: https://data.tuik.gov.tr/Kategori/ GetKategori?p=Istihdam,-Issizlik-ve-Ucret-108 (accessed on 17 October 2021).

42. Aslan, F.; Armağan, G. Socio-economic structure and life satisfaction in rural areas: The case of Aydın. Adnan Menderes Üniversitesi Ziraat Fakültesi Derg. 2020, 17, 71-80. [CrossRef]

43. Aydoğdu, M.H. A research on the perspectives and satisfactions of women working in agriculture sector. Harran Tarmm Ve Gida Bilim. Derg. 2019, 23, 380-390. [CrossRef]

44. Eğinli, A.T. Job satisfaction in employees: A research on job satisfaction of public and private sector employees. Atatürk Üniversitesi Íktisadi Ve İdari Bilim. Derg. 2009, 23, 35-52. 
45. Kim, Y.S. Perception of happiness among health-related university students: Q methodological approach. Indian J. Sci. Technol. 2015, 8, 161-168. [CrossRef]

46. Azizi, M.; Mohamadian, F.; Ghjarieah, M.; Moghadam-Direkvand, A. The affect of individual factors, socioeconomic and social participation on individual happiness: A cross-sectional study. J. Clin. Diagn. Res. 2017, 11, VC01-VC04. [CrossRef] [PubMed]

47. Uzundumlu, A.S. The significance and position of agricultural sector in the country's economy. Alinteri Zirai Bilim. Derg. 2012, 22, 34-44.

48. Türkdoğan, O. The Structure of Turkish Society from the Ottomans to the Present, 1st ed.; Çizgi Publishing: Konya, Turkey, 2015; ISBN 978-605-9108-12-6.

49. Republic of Turkey Ministry of Industry and Technology, Southeastern Anatolia Project (GAP) Regional Development Administration. What's GAP. Available online: http:/ / www.gap.gov.tr/en/ (accessed on 16 October 2021).

50. Manc1, A.R.; Aydoğdu, M.H. A research using willingness to pay method to evaluate economic value of Urfa Castle. J. Acad. Soc. Sci. 2015, 13, 353-368.

51. Neumeier, S.; Pollermann, K. Rural tourism as promoter of rural development-prospects and limitations: Case study findings from a pilot projectpromoting village tourism. Eur. Countrys. 2014, 6, 270-296. [CrossRef]

52. Nagaraju, L.G.; Chandrashekara, B. Rural tourism and rural development in India. Int. J. Interdiscip. Multidiscip. Stud. IJIMS 2014, 1, 42-48.

53. Republic of Turkey Ministry of Industry and Technology, Southeastern Anatolia Project (GAP) Regional Development Administration. GAP and Agriculture. Available online: http://www.gap.gov.tr/tarim-sayfa-15.html (accessed on 16 October 2021).

54. TURKSTAT. Basic Statistics, Population of Turkey. Available online: https:/ / data.tuik.gov.tr/Bulten/Index?p=Adrese-DayaliNufus-Kayit-Sistemi-Sonuclari-2020-37210 (accessed on 11 June 2021).

55. Republic of Turkey Ministry of Industry and Technology, Southeastern Anatolia Project (GAP) Regional Development Administration. Şanlıurfa City Profile. Available online: http://www.gap.gov.tr/upload/dosyalar/pdfler/icerik/IL_profilleri/ SANLIURFA.pdf (accessed on 16 October 2021).

56. Karacadağ Development Agency-Investment Support Office. General Land Distribution and Irrigation Status. Available online: https:/ / www.investsanliurfa.com/sektorler/genel-arazi-dagilimi-ve-sulama-durumu--71 (accessed on 16 October 2021).

57. Aydoğdu, M.H.; Yenigun, K.; Aydoğdu, M. Factors affecting farmers' satisfaction from water users association in the Harran Plain-GAP Region, Turkey. J. Agric. Sci. Technol. 2015, 17, 1669-1684.

58. Bayram, N. Data Analysis with SPSS in Social Sciences, 5th ed.; Ezgi Publish: Bursa, Turkey, 2015; ISBN 978-975-8606-43-3.

59. Elliott, A.C.; Woodward, W.A. Statistical Analysis Quick Reference Guidebook: With SPSS Examples, 1st ed.; Sage Publications, Inc.: Newbury Park, CA, USA, 2007; ISBN 1-4129-2560-6.

60. Mert, M. Horizontal Section Data Analysis Computer Applications, 1st ed.; Detay Publications: Ankara, Turkey, 2016; ISBN 978-6059189-92-7.

61. Hosmer, D.W.; Lemeshow, S.; Sturdivant, R.X. Applied Logistic Regression, 3rd ed.; John Wiley \& Sons. Inc.: New Jersey, NJ, USA, 2013; ISBN 978-0-470-58247-3.

62. Easterlin, R.A. Explaining happiness. Proc. Natl. Acad. Sci. USA 2003, 100, 11176-11183. [CrossRef]

63. Davran, M.K.; Sevinç, M.R.; Cançelik, M. Demographic and socio-economic status of the elderly in the villages of Şanlıurfa province and perceptions of poverty and old age. Elektron. Sos. Bilim. Derg. 2020, 19, 1-17. [CrossRef]

64. Wikipedia. Happiness. Available online: https://en.wikipedia.org/wiki/Happiness (accessed on 11 September 2021).

65. Bozkurt, M.; Aybek, A. Agricultural structure and mechanization properties in Şanlıurfa-Harran Plain. KSÜ Doğa Bil Derg 2016, 19, 319-331.

66. Manc1, A.; Eren, M. Risk analysis of agricultural business in Harran Plain. Harran Tarım Ve Gıda Bilim. Derg. 2017, 21, 456-465. [CrossRef]

67. Sevinç, M.R. Farmers' perception of agricultural cooperatives: The case of Şanlıurfa, Turkey. Ciênc. Rural 2021, 51, e20200445. [CrossRef]

68. Maharajh, S.; Pemberton, C.; Sormeaux, A.D.; Andrews, H.P. Are cocoa farmers in Trinidad happy? Exploring factors affecting their happiness. Farm Bus. J. Caribb. Agro-Econ. Soc. 2018, 10, 14-32.

69. Duc, N.M. Aquaculture and Happiness-a Micro Econometric Analysis in Vietnam; International Institute of Fisheries Economics \& Trade: Nha Trang, Vietnam, 2008; Volume 08-A08, pp. 1-12.

70. Markunsen, T.; Febaek, M.; Tarp, F.; Tuan, N.D.A. The happy farmer: Self-employment and subjective well-being in rural Vietnam. J. Happiness Stud. 2018, 19, 1613-1636. [CrossRef]

71. Savari, M.; Gharechaee, H. Application of the extended theory of planned behavior to predict Iranian farmers' intention for safe use of chemical fertilizers. J. Clean. Prod. 2020, 263, 121512. [CrossRef]

72. Savari, M.; Zhoolideh, M.; Khosravipour, B. Explaining pro-environmental behavior of farmers: A case of rural Iran. Curr. Psychol. 2021, 93, 1-19. [CrossRef]

73. Cook, B.R.; Satizábal, P.; Curnow, J. Humanising agricultural extension: A review. World Dev. 2021, 140, 105337. [CrossRef]

74. Tomashuk, I. Problems and prospects of management of rural development. Balt. J. Econ. Stud. 2017, 3, 214-220. [CrossRef] 
75. Baig, M.B.; Straquadine, G.S. Sustainable Agriculture and Rural Development in the Kingdom of Saudi Arabia: Implications for Agricultural Extension and Education. In Vulnerability of Agriculture, Water and Fisheries to Climate Change: Toward Sustainable Adaptation Strategies; Behnassi, M., Syomiti Muteng'e, M., Ramachandran, G., Shelat, K.N., Eds.; Springer: Dordrecht, The Netherlands, 2014; pp. 101-116. ISBN 978-94-017-8962-2.

76. Aydoğdu, M.H. Evaluation of farmers' willingness to pay for agricultural extension services in GAP-Harran Plain, Turkey. J. Agric. Sci. Technol. 2017, 19, 785-796.

77. Dedehouanou, S.F.A.; Swinnen, J.; Maertens, M. Does contracting make farmers happy? Evidence from Senegal. Rev. Income Wealth 2013, 59, 138-160. [CrossRef]

78. Ma, W.; Vatsa, P.; Zhou, X.; Zheng, H. Happiness and farm productivity: Insights from maize farmers in China. Int. J. Soc. Econ. 2021. [CrossRef]

79. Das, A.B.; Sahoo, D. Farmers' educational level and agriculture productivity: A study of tribals of KBK districts of Odisha. Int. J. Educ. Econ. Dev. 2012, 3, 363-374. [CrossRef]

80. Paltasingh, K.R.; Goyari, P. Impact of farmer education on farm productivity under varying technologies: Case of paddy growers in India. Agric. Food Econ. 2018, 6, 7. [CrossRef]

81. Eric, O.O.; Prince, A.A.; Elfreda, A.N.A. Effects of education on the agricultural productivity of farmers in the Offinso Municipality. Int. J. Dev. Res. 2014, 4, 1951-1960.

82. Luh, Y.H. The impact of education on agricultural productivity: Evidence from East Asian economies. Int. J. Food Agric. Econ. 2017, 5, 11-24. [CrossRef]

83. Korgitet, H.S. The effect of farmers education on farm productivity: Evidence from small- scale maize producing farmers in North Bench District, Bench Maji Zone. Am. J. Des. 2019, 1, 94. [CrossRef]

84. Damane, A.; Habte, D. Effect of non-farm income on rural household livelihood: A case study of Moyale District Oromia Regional State, Ethiopia. Am. Sci. Res. J. Eng. Technol. Sci. ASRJETS 2017, 33, 10-36.

85. Anang, B.T.; Nkrumah-Ennin, K.; Nyaaba, J.A. Does off-farm work improve farm income? empirical evidence from Tolon District in Northern Ghana. Adv. Agric. 2020, 2020, e1406594. [CrossRef]

86. Rashidin, M.S.; Javed, S.; Liu, B.; Jian, W. Ramifications of households' nonfarm income on agricultural productivity: Evidence from a rural area of Pakistan. SAGE Open 2020, 17, 108-123. [CrossRef]

87. Duong, P.B.; Thanh, P.T.; Ancev, T. Impacts of off-farm employment on welfare, food security and poverty: Evidence from rural Vietnam. Int. J. Soc. Welf. 2021, 30, 84-96. [CrossRef]

88. Aydoğdu, M.H.; Aydoğdu, İ.; Cevheri, C.; Sevinç, M.R.; Küçük, N. Analysis of the socio-economic profile of fodder crops producer farmers' in Şanlıurfa. J. Ekon. 2020, 10-15, Special Issue.

89. Sansoucy, R. Livestock-a Driving Force for Food Security and Sustainable Development. Available online: https://www.fao.org/ 3/v8180t/v8180t07.htm (accessed on 21 October 2021).

90. Graham, C. Insights on Development from the Economics of Happiness. Available online: https://openknowledge.worldbank org/handle/10986/16402 (accessed on 20 October 2021).

91. Clark, A.E.; Frijters, P.; Shields, M.A. Relative income, happiness, and utility: An explanation for the easterlin paradox and other puzzles. J. Econ. Lit. 2008, 46, 95-144. [CrossRef]

92. Farid, M.; Lazarus, H. Subjective well-being in rich and poor countries. J. Manag. Dev. 2008, 27, 1053-1065. [CrossRef]

93. Herrera, B.; Bentaya-Gerster, M.; Knierim, A. Farm-level factors influencing farmers' satisfaction with their work. Available online: https:/ /ageconsearch.umn.edu/record/277024/ (accessed on 20 October 2021).

94. Kamarudin, R.; Ali, J.; Mohd Saad, N. Happiness and its influencing factors among paddy farmers in Granary Area of Mada. World Appl. Sci. J. 2013, 28, 91-99.

95. Frijters, P.; Beatton, T. The mystery of the U-shaped relationship between happiness and age. J. Econ. Behav. Organ. 2012, 82, 525-542. [CrossRef] 